\title{
Tertiary sedimentary development of the Broad Fourteens area, the Netherlands
}

\author{
Th.E.Wong ${ }^{1,2}$, N. Parker $^{3} \&$ P. Horst ${ }^{4}$ \\ 1 Corresponding author; e-mail: t.wong@nitg.tno.nl \\ ${ }^{2,3}$ Netherlands Institute of Applied Geoscience-TNO, PO Box 80015, 3508 TA Utrecht, \\ the Netherlands. \\ 4 Amsterdamse straatweg 312 bis, 3551 CT Utrecht, the Netherlands
}

Manuscript received 21 March 2000; accepted in revised form: 16 Feb 2001

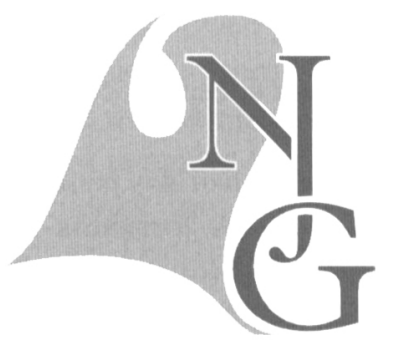

\begin{abstract}
The Broad Fourteens Basin is a NW-SE trending Mesozoic structural element that was affected by inversion movements during the Late Cretaceous (Subhercynian Phase) and Early Tertiary (Laramide Phase). Since the overlying Tertiary section of this area is relatively little studied, a multi-disciplinary investigation was initiated using both seismic and well data. The present study is the first phase of that project and deals exclusively with the stratigraphical framework and sedimentary development based on well logs from approximately forty wells.

The Tertiary sedimentary section in this area (maximum thickness up to approximately $800 \mathrm{~m}$ ) consists of siliciclastic rocks that generally correlate well with the established lithostratigraphical framework of the Netherlands. However, the highly variable thickness of these lithological units, illustrated by isopach maps for all units, reflect the intricate pattern of sea level movements, differential vertical movements and the ensuing erosion, that took place in this tectonically active area.

Well P06-02, one of the most complete sections in the center of the area, was selected for detailed biostratigraphical analysis to support further stratigraphical subdivision and correlation. This yielded information on both the distribution pattern of various lithological units and the influence of large, partly global, events during basin development. It is concluded that application of detailed sequence stratigraphy in the study area is very problematic and only $2^{\text {nd }}$ and some $3^{\text {rd }}$ order cycles could be recognized.
\end{abstract}

Keyzords: Broad Fourteens Basin, stratigraphy, Tertiary, the Netherlands

\section{Introduction}

The Broad Fourteens area is located between longitude $3^{\circ}$ and $4^{\circ} 30^{\prime}$ and latitude $52^{\circ} 30^{\prime}$ and $53^{\circ} 30^{\prime}$, in the southern North Sea. It extends over part of the $K$, L, $P$ and $Q$ quadrants (Figure 1). The Broad Fourteens Basin proper is a NW-SE trending Mesozoic structural element (Figure 2) that was affected by inversion movements during the Late Cretaceous (Subhercynian phase) and Early Tertiary (Laramide phase). Several publications specifically deal with the pre-Tertiary geology of the Broad Fourteens Basin (i.e. Van Wijhe, 1987a, 1987b; Dronkers \& Mrozek, 1991; Roelofsen \& De Boer, 1991, Nalpas et al.,
1995). No detailed research has so far been done on the overlying, relatively thick (up to $800 \mathrm{~m}$ ), Tertiary section. Various regional studies about the Tertiary in the Netherlands exist (i.e. Letsch \& Sissingh, 1983 and Zagwijn, 1989), whereas detailed studies of the Paleogene section in western Belgium have been carried out by i.e. Jacobs (1995a; b), Jacobs \& De Batist (1996) and Steurbaut (1998). To successfully model the entire history of this area, data on the Tertiary section should also be incorporated. Therefore, a research project was initiated to specially investigate the geological development of the Broad Fourteens area during the Tertiary. The present study is the first phase of that project and deals exclusively with the 


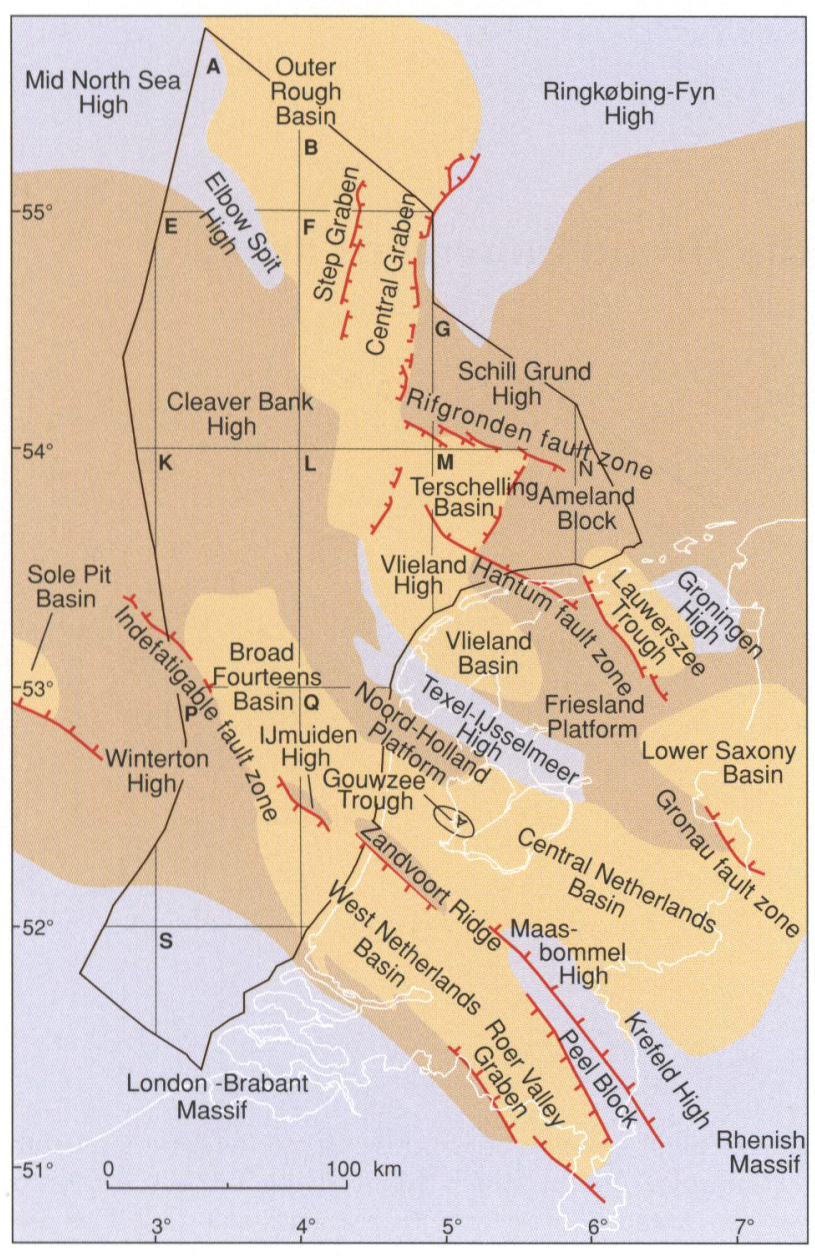

Fig. 1. Structural setting of the Broad Fourteens area.

stratigraphical framework and sedimentary development based on well logs from approximately forty wells. Subsequent phases of the project will include detailed seismic interpretation and mapping of Tertiary reflectors and 3D- modeling of the various stratigraphical units.

Since the Tertiary section in this area was not an exploration target for oil companies, adequate logging of this interval had a relatively low priority. Consequently the completeness and quality of the data set varies remarkably from well to well. For our study we have tried to select only representative data consisting of gamma ray and sonic logs, but that was not always possible.

In this study we follow the standard lithological subdivision of the Tertiary, as outlined in Van Adrichem Boogaert \& Kouwe (1997). A reference well (P0602 ), which penetrated one of the most complete sections in the center of the area, was selected for detailed biostratigraphical analysis to support further stratigraphical subdivision (Figures $3 \& 4$ ) and correlation (Figures $5 \& 6$ ). This yielded information on

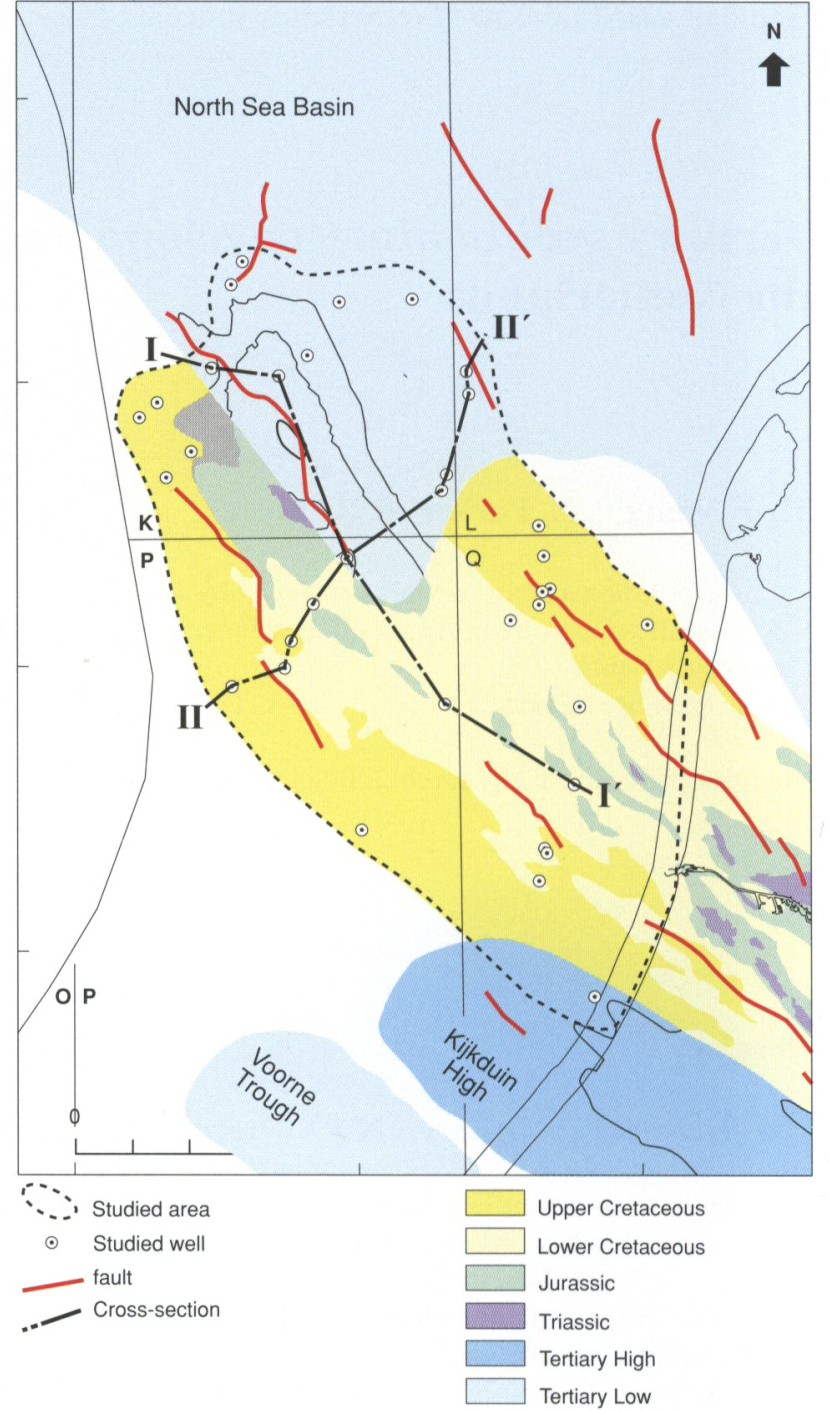

Fig. 2. Outline of the Broad Fourteens area with subcrop map of the Tertiary.

both the distribution pattern of various lithological units and the influence of large, partly global, events during basin development. Isopach maps for all lithological units and depth maps of the base and the top of the Tertiary were made (Figures 5-16). Finally an attempt was made to link our lithostratigraphic subdivision (Figures $3 \& 4$ ) with sequence stratigraphical charts as published by Haq et al. (1988), Van Wagoner et al. (1987) and Vinken (1988),

\section{Geological setting}

\section{Pre-Tertiary}

The Broad Fourteens Basin is associated with the northern margin of the stable London Brabant Massif and its position, just like those of adjacent basins, is related to late Variscan and Hercynian fault systems (Figure 1). According to Heybroek (1974), the preTertiary structural configuration is a graben, approxi- 


\section{Reference well P06-02}

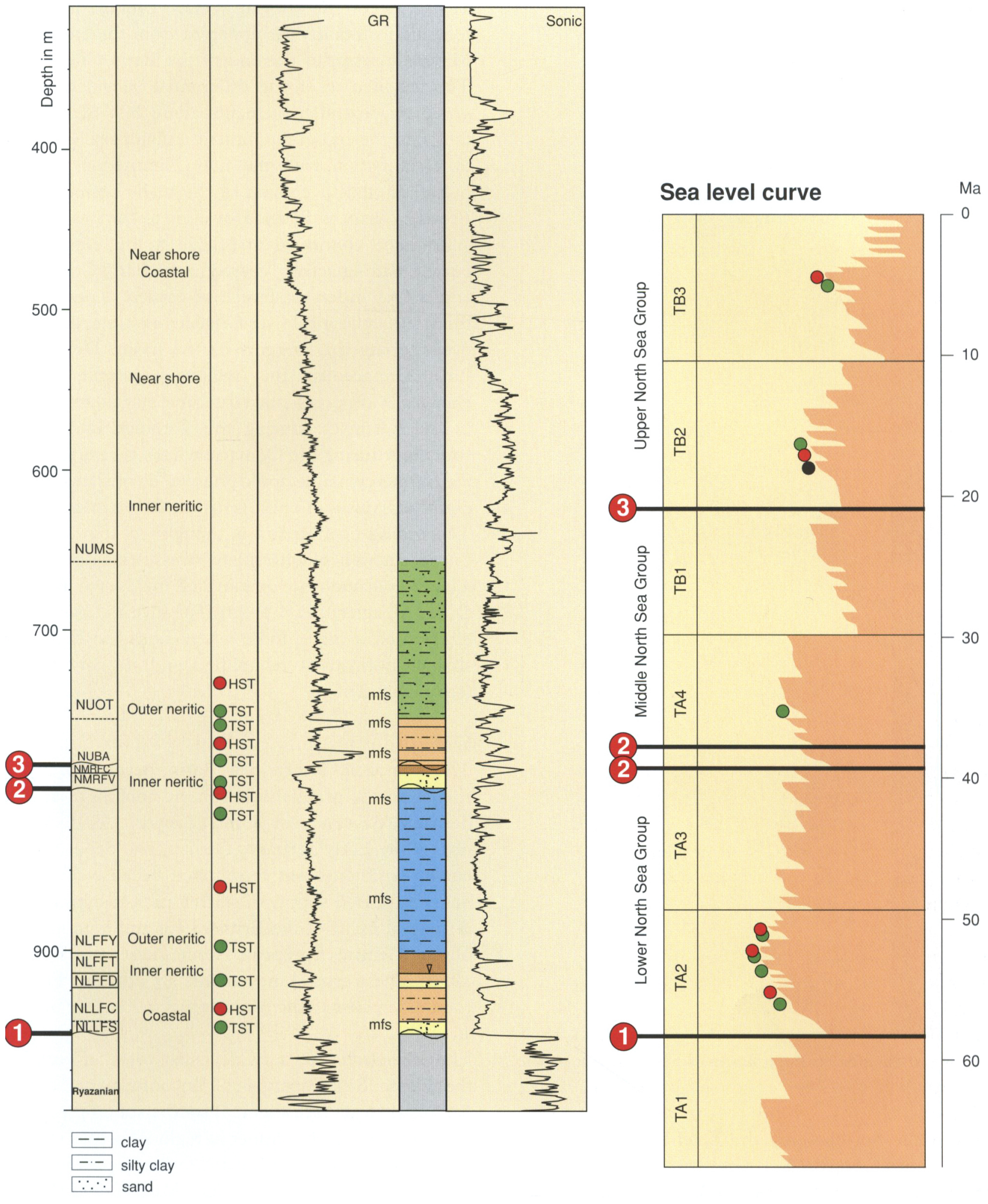

Fig. 3. Stratigraphical subdivision in reference well P06-02 and correlation with the sea level curve cf. Haq et al., 1988. NLLFS = Heers Member, NLLFC = Landen Clay Member, NLFFD = Basal Dongen Sand Member, NLFFT $=$ Basal Dongen Tuffite Member, NLFFY $=$ Ieper Member, NMRFV = Vessem Member, NMFRC $=$ Rupel Clay Member, NUBA = Breda Formation, NUOT = Oosterhout Formation, NUMS $=$ Maassluis Formation, $\mathrm{TST}=$ transgressive system tract, $\mathrm{HST}=$ highstand system tract, $\mathrm{mfs}=$ maximum flooding surface .

mately $45 \mathrm{~km}$ wide and $120 \mathrm{~km}$ long with a slightly different direction $\left(330^{\circ}\right)$ from the other adjacent basins $\left(300^{\circ}\right)$. It is flanked to the west by the Winterton High, to the southeast by the Zandvoort Ridge 


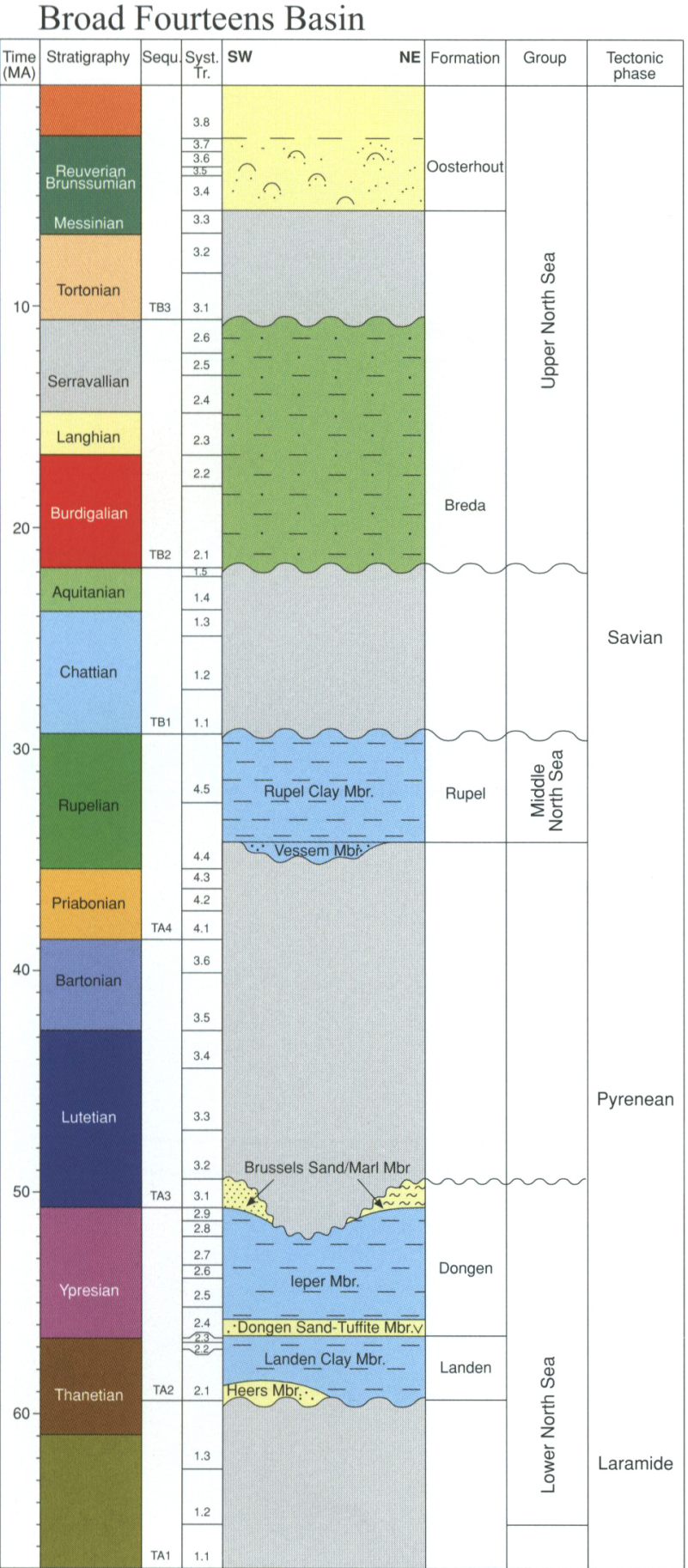

Fig. 4. Late Paleocene to Early Miocene litho-chronostratigraphic chart Broad Fourteens area.

and to the northeast by the Texel-IJsselmeer High. The Central North Sea Graben, the Terschelling Basin and the Vlieland Basin adjoin it to the northeast, the Sole Pit Basin to the northwest and the Central and West Netherlands Basins to the southeast. The boundary is clearly defined in the southwest, but to the northeast, the basin passes progressively into an intermediate platform zone.

The basin started to develop in the Early Triassic as a result of crustal extension (Harding, 1983; Ziegler, 1990). According to Van Wijhe (1987a), increased tectonic instability was apparent from the end of the Middle Jurassic to the end of the Early Cretaceous. This resulted in strong differential subsidence governed by dextral movements along NW-SE striking faults. At the end of the Jurassic a major sea level drop in combination with the Late Kimmerian tectonic pulse resulted in erosion of the highs bounding the Broad Fourteens Basin. However, in the basin itself, subsidence continued and little to no erosion occurred. Rifting activity ceased in the Early Cretaceous and a first order sea-level rise caused deposition of thick sequences of Lower Cretaceous strata, gradually overstepping the margins of the basin. During the Late Cretaceous, the regional tectonic regime changed. Compressional structures started to develop in the northwest during the Turonian and in the southeast during the Coniacian. This is referred to as the Subhercynian tectonic phase and consisted of several short pulses of uplift (Huyghe \& Mugnier, 1994). The timing of inversion is thought to coincide with the interaction of intra-plate stresses resulting from Alpine collision and opening of the North Atlantic Ocean (Ziegler, 1978, 1990). The inverted basin center formed a large dome where both the deep and shallow horizons were uplifted and strongly eroded (see Figure 2).

\section{Tertiary}

The Cenozoic North Sea Basin developed in response to the gradual lithospheric cooling of an underlying Mesozoic rift dome (Ziegler, 1990). At the end of the Early Tertiary (Danian) the deposition of chalky sediments was terminated because of a suddenly increased supply of siliciclastics, resulting from a thermal uplift of the British Isles and compression of the Central European Alpine foreland (Ziegler, 1990). These crustal movements are attributed to the Laramide phase of the Alpine orogeny.

The siliciclastic Tertiary deposits, together forming the North Sea Supergroup, unconformably overlie Mesozoic strata (see Figure 2 for the subcrop Tertiary map of the area). A number of regional breaks in sedimentation can be used to divide the succession into three groups, i.e. the Lower, Middle and Upper North Sea Groups. The Lower North Sea Group comprises predominantly Paleocene and Eocene deposits, the Middle North Sea Group includes mainly Oligocene strata, and the Upper North Sea Group comprises all the Miocene and younger deposits. The alternation of sandstones and claystones near the southern margin of the North Sea Basin forms the 


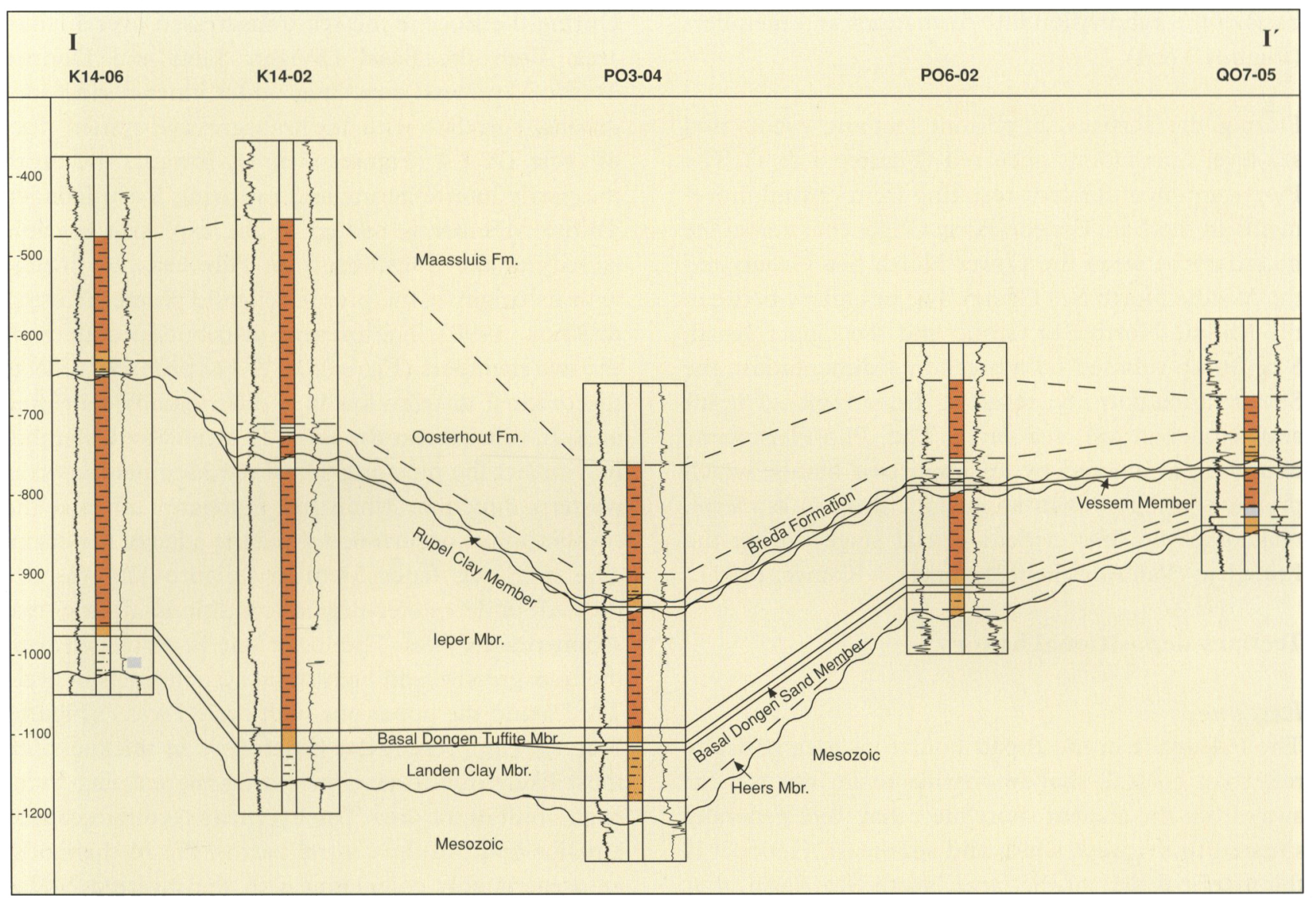

Fig. 5. Tertiary correlation section parallel to the former Broad Fourteens Basin (Section I-I' in Figure 2).

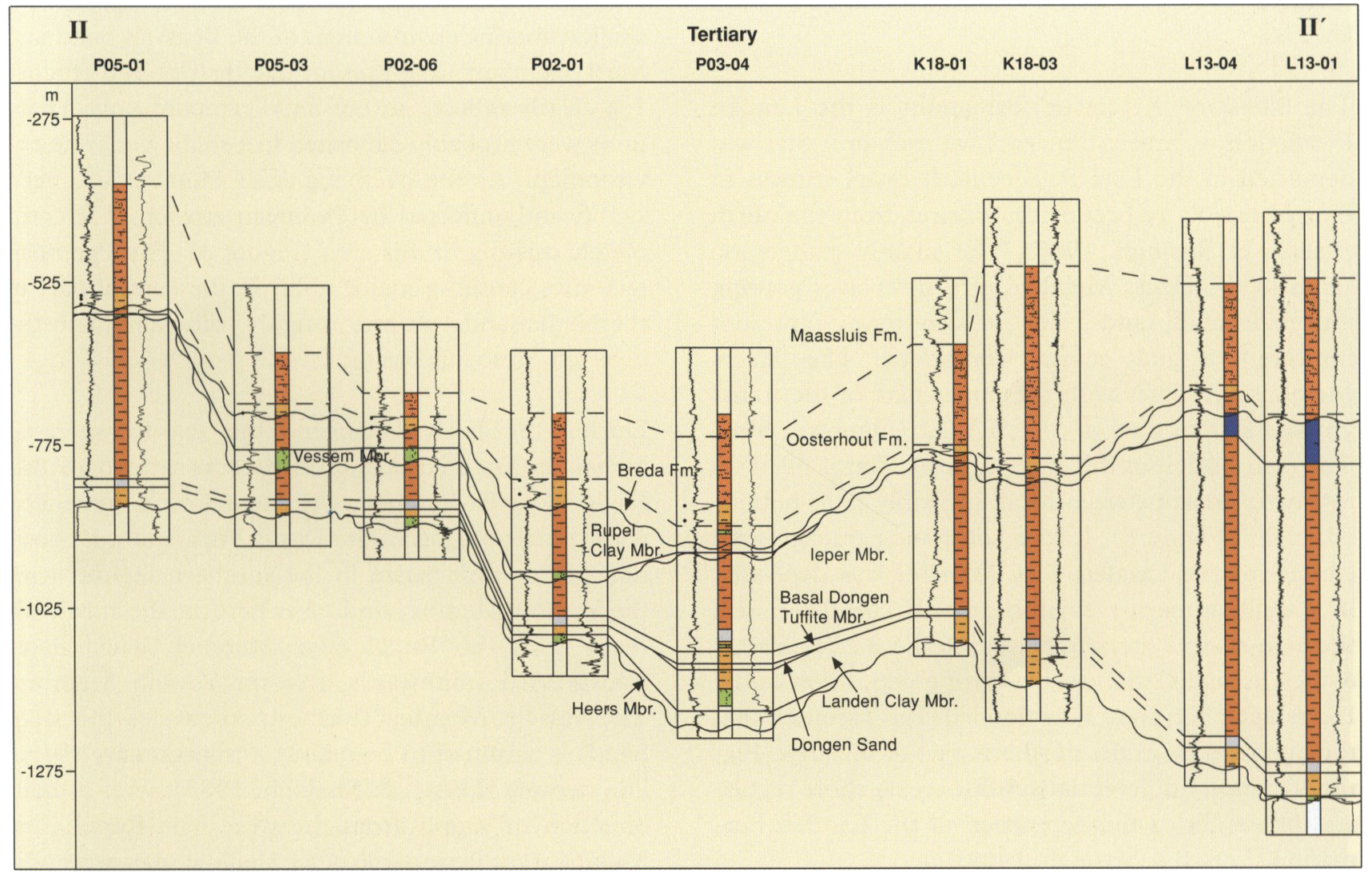

Fig. 6. Tertiary correlation section perpendicular to the former Broad Fourteens Basin (Section II-II' in Figure 2). 
basis of the subdivision into formations and members (Figures $3 \& 4$ ).

During the Tertiary, important tectonic events and sea-level fluctuations occurred (Figures $3 \& 4$ ). The Pyrenean unconformity, resulting from crustal movements in the Late Eocene-Early Oligocene, marks the boundary between the Lower North Sea Group and the Middle North Sea Group. The boundary between the Middle North Sea Group and the Upper North Sea Group is based on a break in sedimentation, the Savian unconformity, resulting from regional uplift and a global low sea level. The Plio-Pleistocene boundary is marked by an important hiatus, which probably resulted from an eustatic drop in sea level, related to the first evident glacial stage during the Pretiglian (Van Adrichem Boogaert \& Kouwe, 1997).

\section{Tertiary depositional history}

\section{Paleogene}

The Paleogene in the Broad Fourteens area basically reflects a coastal, shallow marine realm not too far away from the ancient shorelines, that were generally situated to the west, south and southeast. Hence it is the marginal part of the large North Sea Basin, that came into existence as a result of tensional forces related to additional opening of the North Sea Rift (Ziegler, 1978), combined with a general rise in sea level.

The oldest of the clastic formations is the Landen Formation, a largely transgressive rock-unit that was deposited in the Late Paleocene. It bears witness to the sea rapidly re-occupying the area from the north (Letsch \& Sissingh, 1983). The slightly glauconitic sands of the Heers Member, at some places grading into indurated sand-, silt- or claystones represent transgressive and coastal conditions. The Heers Member correlates with the upper part of the transgressive system tract of cycle TA 2.1 (Figures $3 \& 4$ ). The distribution of this unit suggests, that it filled up low-lying areas between local, probably fault-bounded, highs (Figure 8). Under continuing transgressive conditions the Landen Clay Member was deposited in a shallow marine environment. It correlates with the high-stand system tract of cycle TA 2.1 (Figures 3 \& 4). The highs, that existed during deposition of the Heers Member, were now flooded. It is assumed that the depo-centre in the northern part of the area (Figure 9) reflects differential subsidence. A short regressive phase ended the deposition of the Landen Formation (Letsch \& Sissingh, 1983).
During the Eocene the sea transgressed over a larger area. Both the Basal Dongen Sand and Dongen Tuffite Members, deposited under inner-neritic conditions, correlate with the transgressive system tract of cycle TA 2.4 (Figures $3 \& 4$ ). Towards the north the partly interfingering and overlying Basal Dongen Tuffite Member is related to the explosive volcanic activity at the transition from Paleocene to Eocene with its origin at the proto-Icelandic plume (Morton $\&$ Knox, 1990). The present distribution pattern of the two members (Figures $10 \& 11$ ) probably reflects the original distribution in a differentially subsiding area. In this context the Basal Dongen Sand Member may reflect the pinching out of the Member in northwestern direction, while the Dongen Tuffite is the southernmost occurrence along the edge of the basin. The overlying Ieper Member (Figure 12) was deposited under outer-neritic conditions during two sedimentary cycles. The lower one is correlated with the transgressive and high-stand system tracts of cycle TA 2.5 and the upper one with cycle TA 2.7 (Figures $3 \& 4$ ). The present day differences in thickness are most likely due to erosion during the ensuing Pyrenean uplift of the area. The Pyrenean tectonics caused a major uplift in the central part of the Netherlands, an area roughly coinciding with the inverted Mesozoic basins. This event, which took place at the Eocene-Oligocene transition, was accompanied by a regression that culminated with the deposition in a shallow marine environment of the Brussels Sand and Marl Members. The present day distribution (Figure 13) clearly reflects an erosional remnant only. These units were probably deposited in a shallow marine environment. As the overlying Asse Member has been significantly affected by Pyrenean erosion, it is completely missing in this area (Figure 4). The Pyrenean tectonics caused a major uplift in the central part of the Netherlands, an area roughly coinciding with the inverted Mesozoic basins.

During the Early Oligocene the sea transgressed across the uplifted and eroded areas related to this High and post-Pyrenean sedimentation commenced with the deposition of the Rupel Formation. Deposition of this unit began in the southern regions with the Vessem Member and elsewhere in the north directly with the Rupel Clay Member, which later transgressed southwards over the Vessem Member. The Vessem Member (formerly known as the Berg Sand) is assumed to be mainly a transgressive shoreline deposit (Letsch \& Sissingh, 1983), with a main direction of supply from the west. The Rupel Clay Member was deposited under shallow marine conditions. Both the Vessem and Rupel Clay Members can 


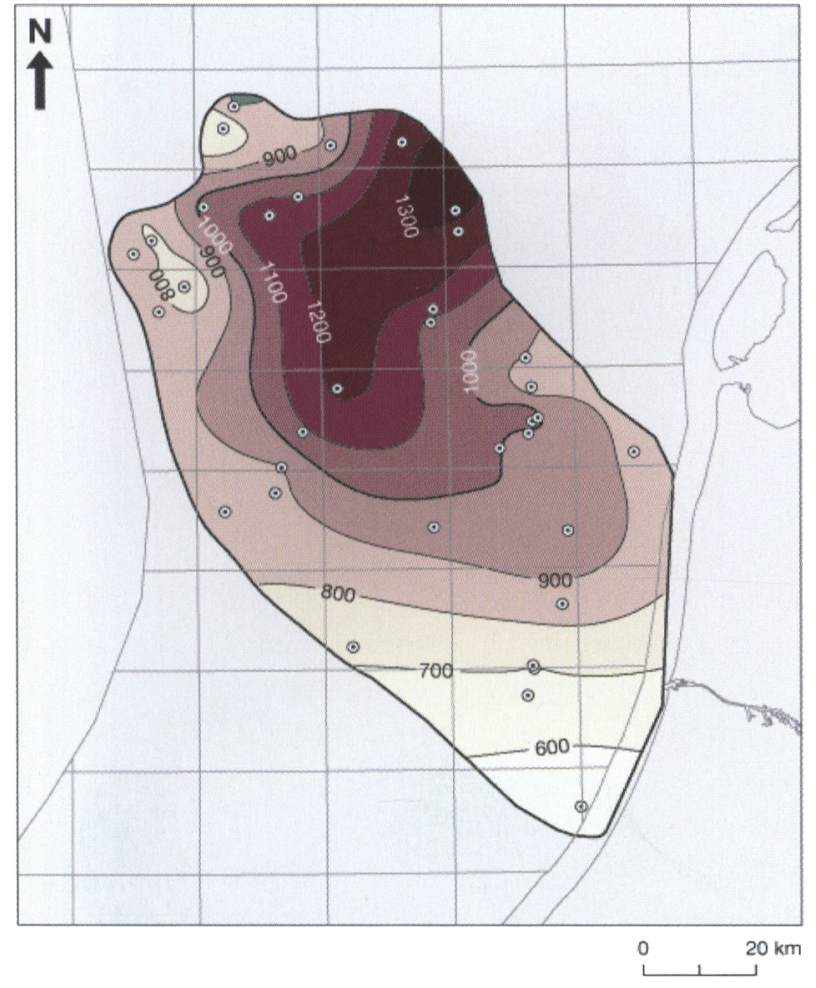

Fig. 7. Depth to Base Tertiary.

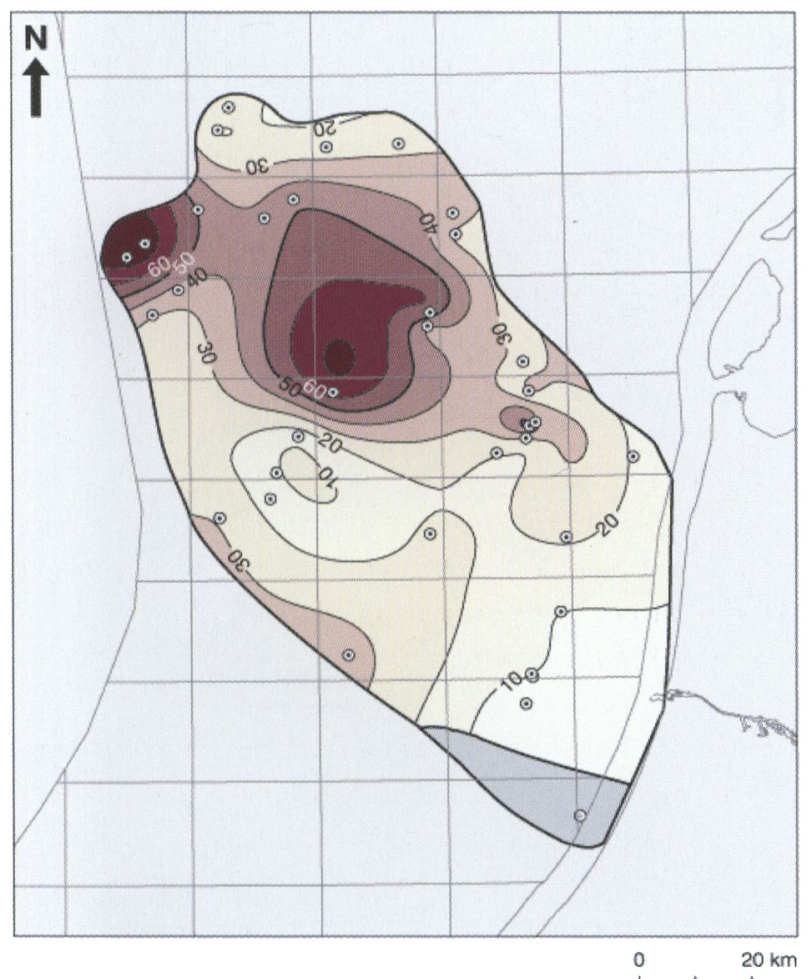

Fig. 9. Tickness map Landen Clay Member.

be correlated with the transgressive system tract of cycle TA 4.4 (Figures $3 \& 4$ ). According to our thickness maps (Figures $14 \& 15$ ), the depo-centre had shifted towards the south relatively to the position of the Paleocene-Eocene depo-centres. This suggests

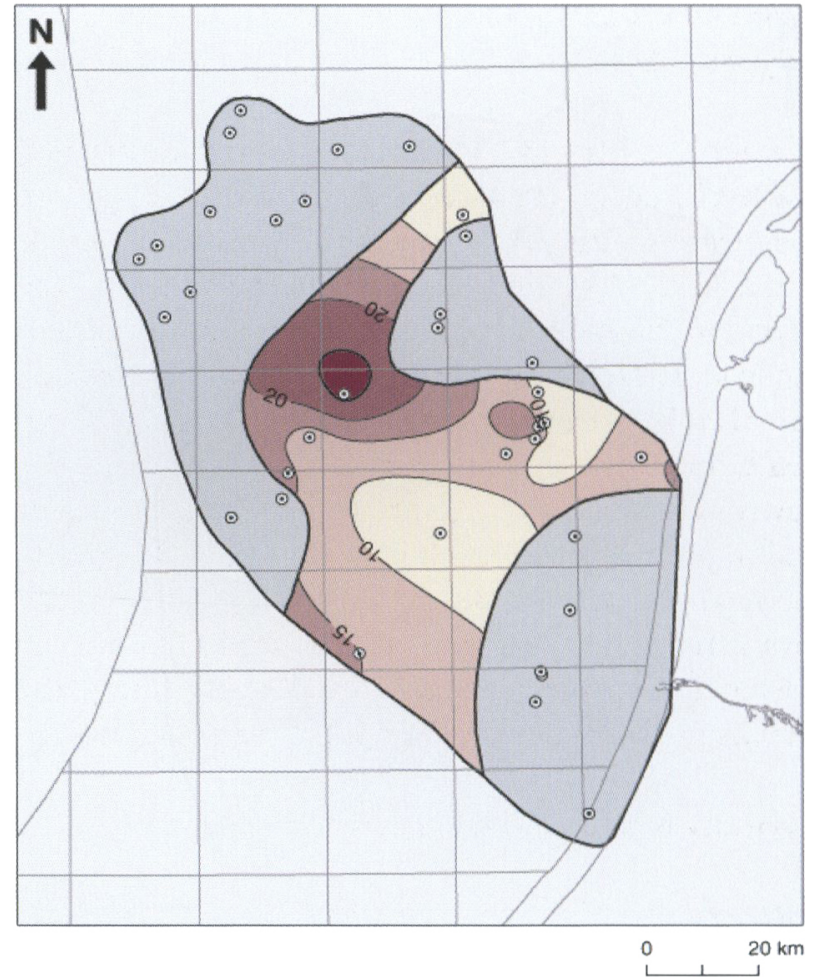

Fig. 8. Thickness map Heers Member.

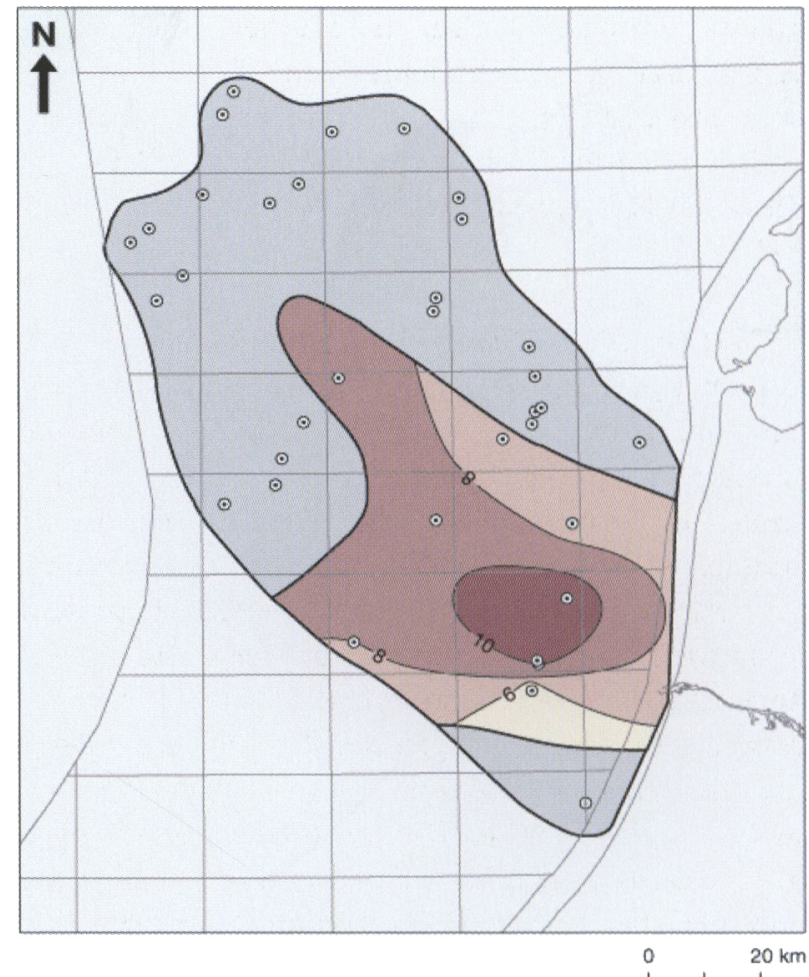

Fig. 10. Tickness map Basal Dongen Sand Member.

some of differential subsidence in the area. Towards the end of the Middle Oligocene regression, deposition of the Rupel Formation ended. However, the overlying deposits of the Veldhoven Formation have not been encountered in the area. They have been re- 


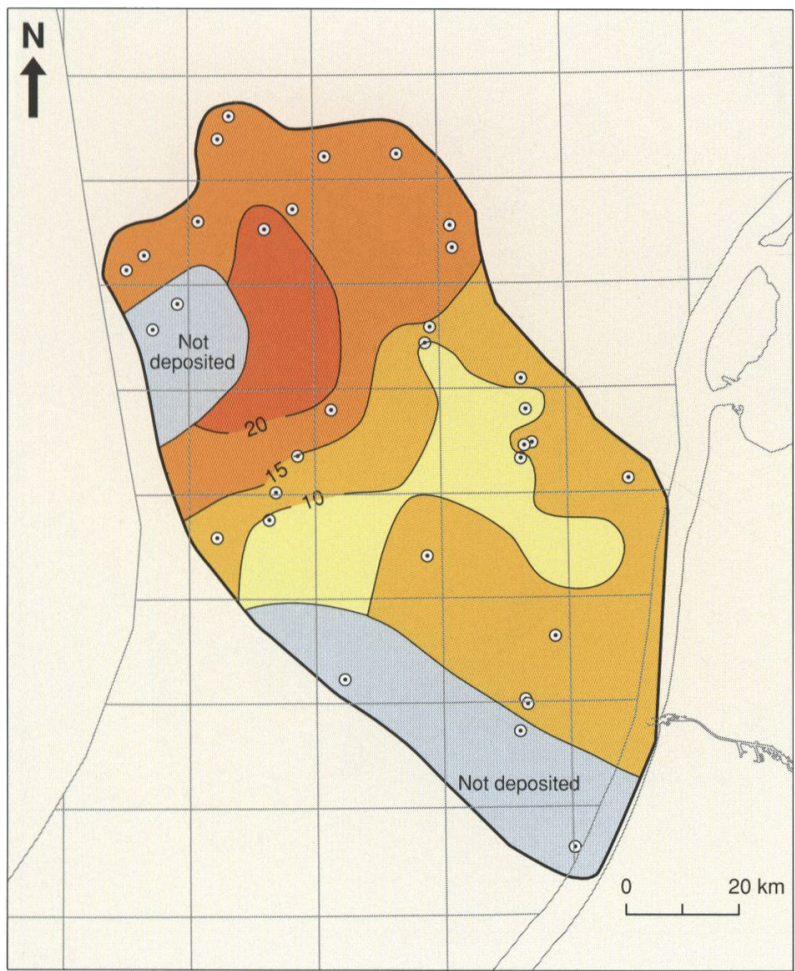

Fig. 11. Thickness map Basal Dongen Tuffite Member.

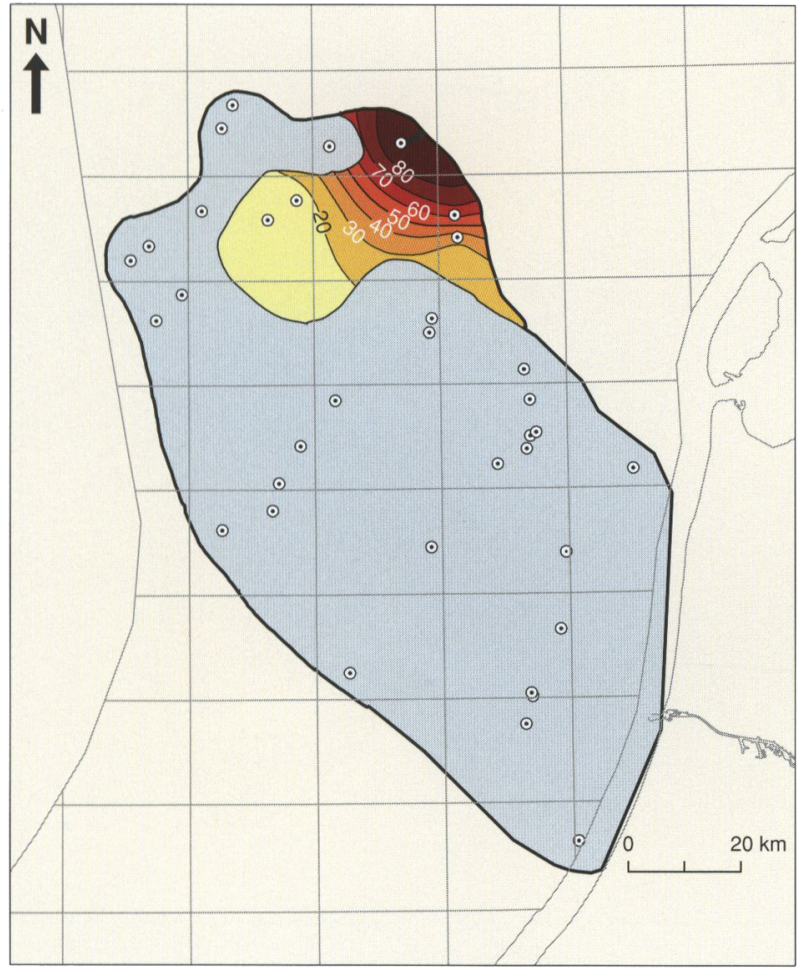

Fig. 13. Thickness map Brussels Sand Member and Brussels Marl Member.

moved during the Savian phase. Regional uplift and a global low sea level resulted in a break in sedimentation and regional erosion at the end of the Oligocene (Van Adrichem Boogaert \& Kouwe, 1997).

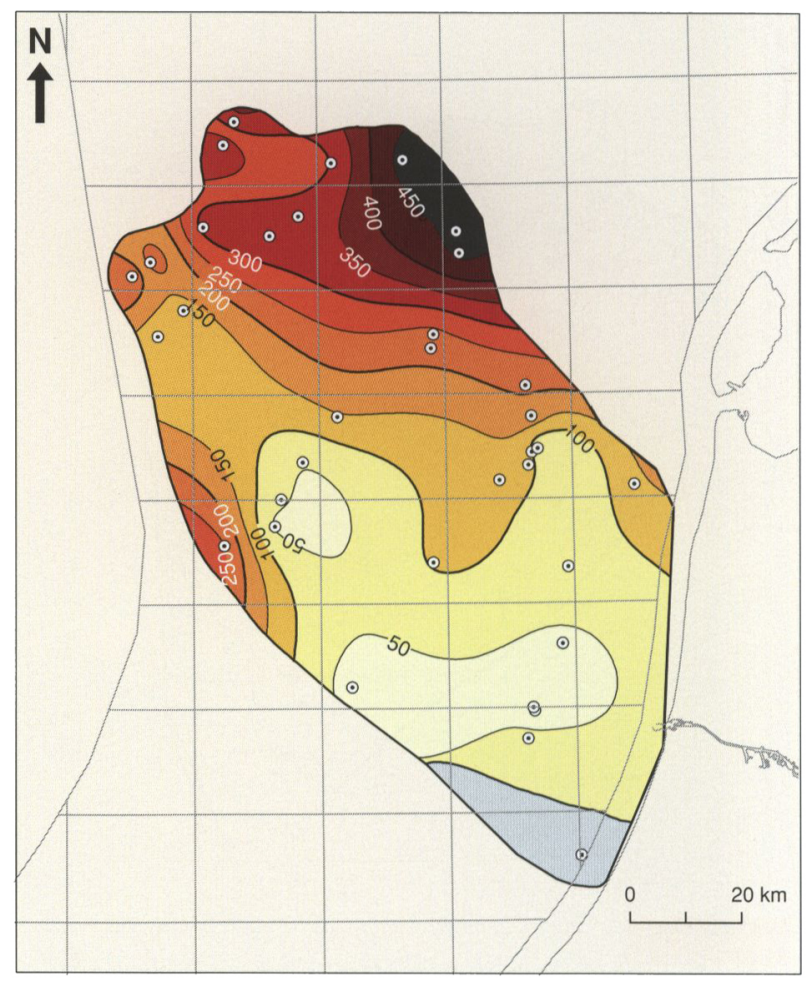

Fig. 12. Thickness map Iepe Member.

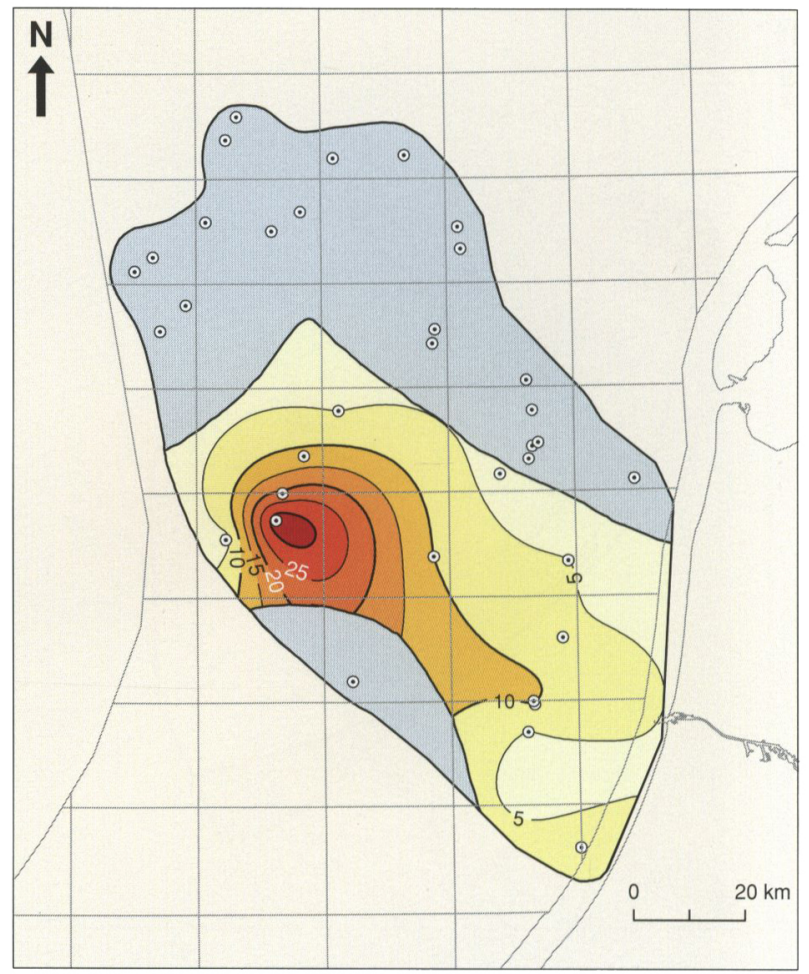

Fig. 14. Thickness map of the Vessem Member.

\section{Neogene}

The Neogene in the Broad Fourteens area is characterized as a period of infilling of depressions, and consequently shallowing, of the area. The patterns of sediment accumulation and the location of the coastlines 


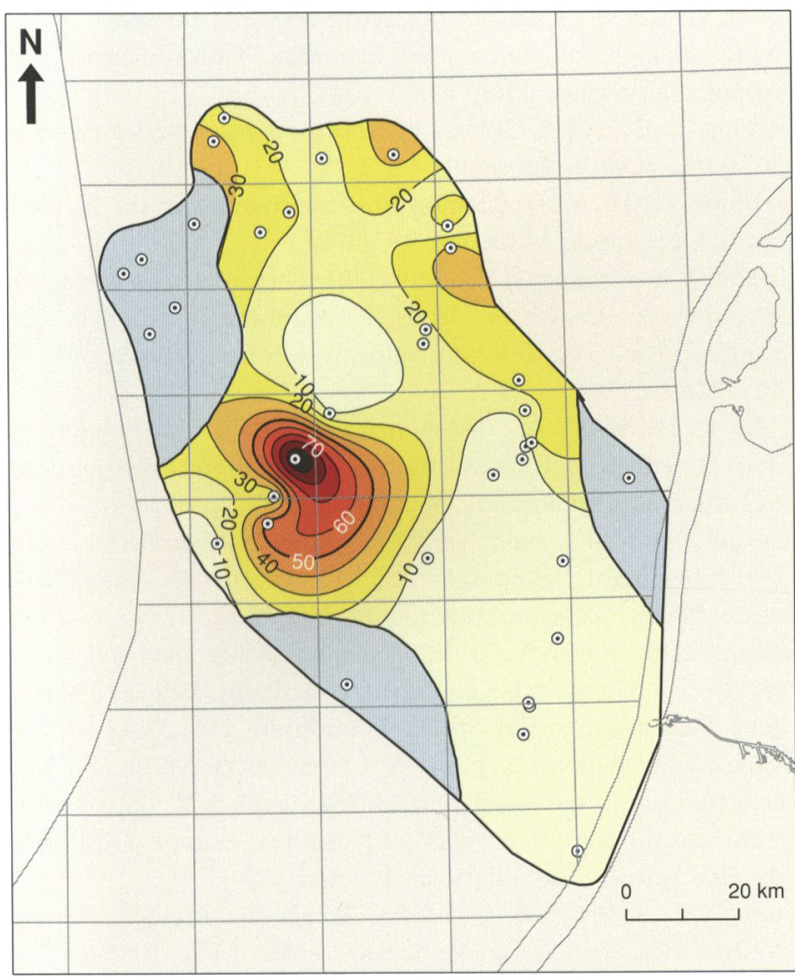

Fig. 15. Thickness map of the Rupel Clay Member.

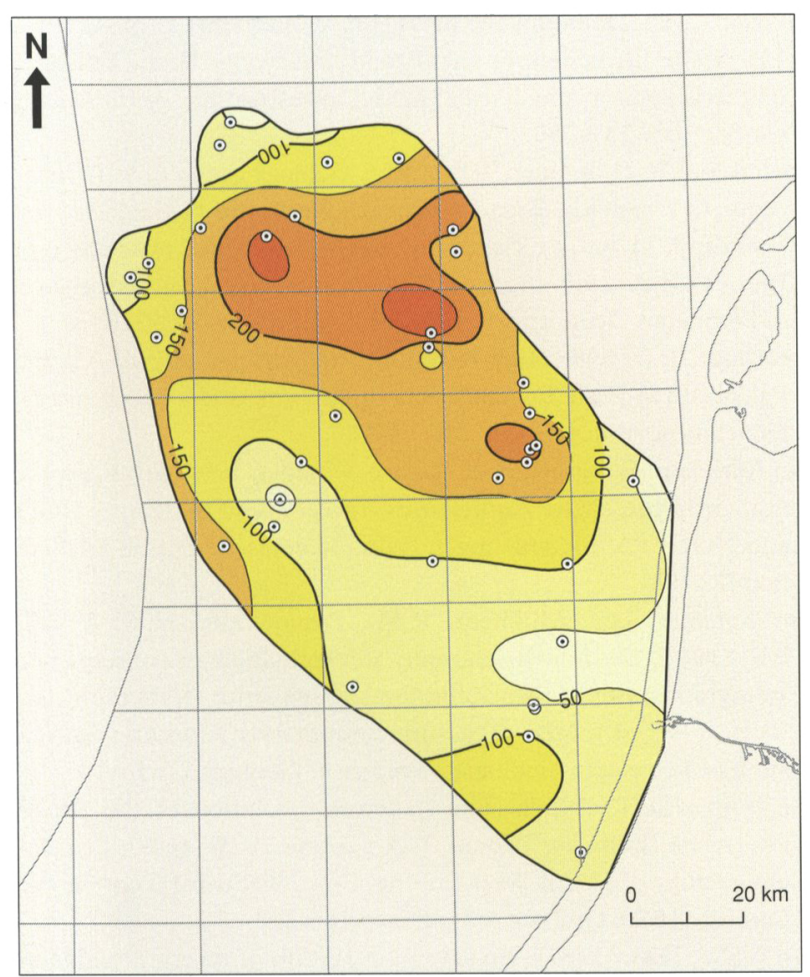

Fig. 17. Thickness map of the Oosterhout Formation.

were strongly influenced by repeated glacio-eustatic sea-level fluctuations (Van Adrichem Boogaert \& Kouwe, 1997).

\section{Deposition of the Neogene Breda Formation began}

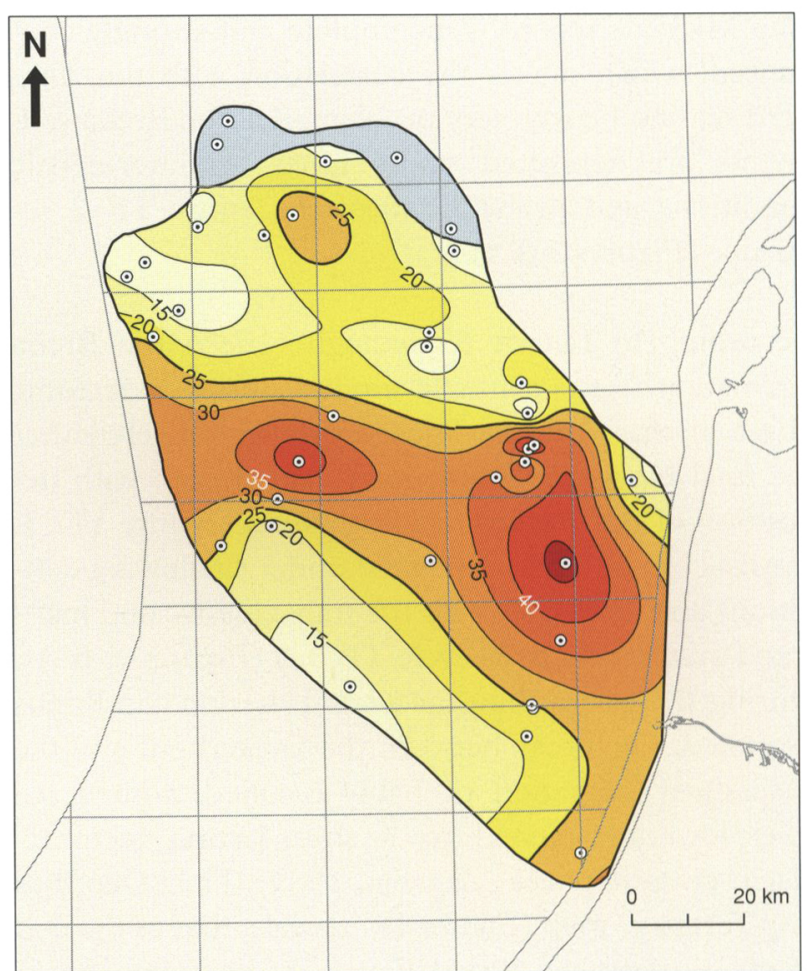

Fig. 16. Thickness map of the Breda Formation.

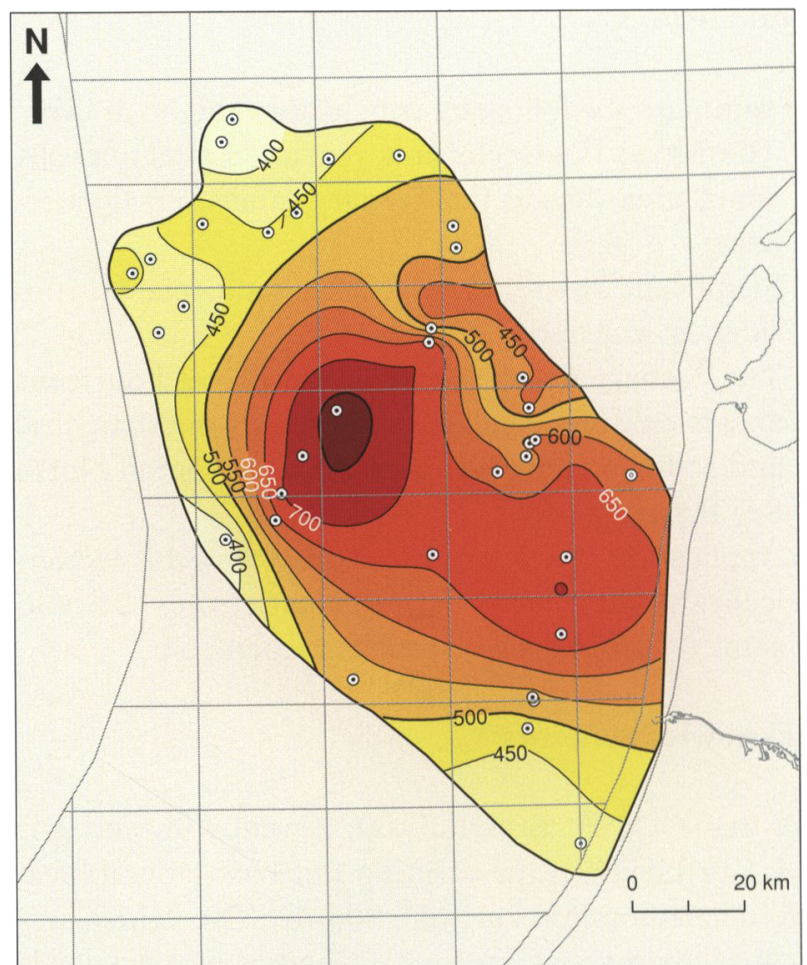

Fig. 18. Depth to top Tertiary.

during the Middle Miocene (Figure 16), when marine conditions resumed after the Savian regressive and tectonic phase. From the Miocene onwards an overall regressive trend with a number of superimposed transgressions is assumed to have taken place. 
The Miocene record is incomplete and strongly condensed, which makes the correlation with the standard sea-level curve very problematic. The Breda sediments are deposited under inner to outer-neritic conditions and probably cover the entire TB 2 sequence (Figures $3 \& 4$ ).

According to Letsch \& Sissingh (1983) the Breda Formation was essentially eroded during a tectonic phase at the Miocene-Pliocene transition. Hereafter the final Neogene sedimentary cycle began with deposition of the Oosterhout Formation (Figure 17). It consists of one cycle deposited under shallowing conditions and correlates with the transgressive and highstand system tracts of cycle TB 3.4 (Figures $3 \& 4$ ). During the entire Pliocene period marine conditions prevailed. The break between the Oosterhout and the Maassluis Formation probably resulted from a sea level lowering related to a short-lasting tectonicglacio-eustatic phase (Zagwijn, 1989). The "Depth to Top Tertiary" map (Figure 18) reveals, that at the end of the Tertiary, the Broad Fourteens area once again developed into a (local) depo-centre.

\section{Conclusions}

In summary the following conclusions can be drawn:

- The Broad Fourteens area remained a tectonically active area during the Tertiary (and even Quaternary).

- Significant differential, probably fault-related, subsidence occurred.

- The Tertiary development of the Broad Fourteens area is very representative for the existing structural and sedimentary development of the Dutch North Sea Basin.

- Application of sequence stratigraphy in this tectonically unstable area is problematic, only $2^{\text {nd }}$ and some $3^{\text {rd }}$ order cycles could be recognized.

\section{Acknowledgements}

We thank Dr H. Brinkhuis, D. Zevenboom and Dr. R.J. Van Leeuwen for carrying out biostratigraphical age determinations on well P06-02. The critical review of the manuscript by $M$. Geluk is also acknowledged.

\section{References}

Dronkers, A.J. \& Mrozek, F.J., 1991. Inverted basins of the Netherlands. First Break 9: 409-425.

Haq, B.U., Hardenbol, J. \& Vail, P.R, 1988. Mesozoic and Cenozoic chronostratigraphy and cycles of sea-level change. In: Wilgus, C.K., Hastings, B.C., Kendall, C.G.S.C., Posamentier, H.W.,
Ross, C.A. \& Van Wagoner, J.C. (eds): Sea-level changes - An integrated approach. Society of Economic Paleontologists and Mineralogists. Spec. Publ. 42: 71-108.

Harding, T. P., 1983. Graben hydrocarbon plays and structural styles. Geologie en Mijnbouw 62: 3-23.

Heybroek, P., 1974. Explanation to tectonic maps of the Netherlands. Geologie en Mijnbouw 53: 43-50.

Huyghe, P. \& Mugnier, J.-L., 1994. Intra-plate stresses and basin inversion: A case history from the Southern North Sea . In: Roure, F. (ed.) Peri-Tethian Platforms, Edition Technique, Paris: 211-226.

Jacobs, P., 1995a. Eocene sediment supply in Western Belgium as determined through heavy mineral distribution. Contributions to Tertiary and Quaternary Geology 32: 32-52.

Jacobs, P., 1995b. Eocene to early Oligocene deltas in the Southern North Sea Bight, Belgium. In: Oti, M. \& Postma, G. (eds): Geology of Deltas. Balkema, Rotterdam: 139-152.

Jacobs, P. \& De Batist, M., 1996. Sequence stratigraphy and architecture on a ramp-type continental shelf: the Belgian Palaeogene. Geological Society Special Publications 117: 23-48.

Jacqué, M. \& Thouvenin, J., 1975. Lower Tertiary tuffs and volcanic activity in the North Sea. In: Woodland, A.W. (ed.): Petroleum and the continental shelf of Northwest Europe, I Geology. Applied Science Publ., Barking: 455-465.

Letsch, W.J. \& Sissingh, W., 1983. Tertiary stratigraphy of the Netherlands. Geologie en Mijnbouw 62: 305-318.

Morton, A.C. \& Knox, R.W.O.B., 1990. Geochemistry of late Paleocene and early Eocene tephras from the North Sea Basin. Journal of the Geological Society 147: 425-437.

Nalpas, T., Le Douaran, S., Brun, J.P., Unternehr, P. \& Richard, J.P., 1995. Inversion of the Broad Fourteens Basin (offshore Netherlands), a small-scale model investigation. Sedimentary Geology 95: 237-250.

Roelofsen, J.W. \& de Boer, W.D., 1991. Geology of the Lower Cretaceous $\mathrm{Q} / 1$ oilfields, Broad Fourteens basin, the Netherlands. In: Spencer A.M. (ed.): Generation, accumulation, and production of Europe's hydrocarbons. Special Publication European Association of Petroleum Geoscientists 1, Oxford Univ. Press: 203-216

Steurbaut, E., 1998. High-resolution holostratigraphy of Middle Paleocene to Early Eocene strata in Belgium and adjacent areas. Palaeontographica Abt. A 247: 91-156.

Van Adrichem Boogaert, A. \& Kouwe, W. (eds), 1997. Stratigraphic nomenclature of the Netherlands, revision and update by RGD and NOGEPA. Mededelingen Rijks Geologische Dienst 50, Section I: 1-39.

Van Wagoner, J.C., Mitchum, R.M., Posamentier, H.W. \& Vail, P.R., 1987. Seismic stratigraphy interpretation using sequence stratigraphy, part II: Key definitions of sequence stratigraphy. In: Bally, A.W. (ed.): Atlas of Seismic Stratigraphy. American Association of Petroleum Geologists Studies in Geology 27: 1 - 10.

Van Wijhe, D.H., 1987a. The structural evolution of the Broad Fourteens Basin. In: Brooks, J. \& Glennie, K.W. (eds): Petroleum geology of North-West Europe, Proc. of the 3rd Conference, London, 1986, Graham \& Trotman: 315-323.

Van Wijhe, D.H., 1987b. Structural evolution of inverted basins in the Dutch Offshore. Tectonophysics 137: 171-219.

Vinken, R. (comp.), 1988. The Northwest European Tertiary Basin. Geologisches Jahrbuch A, 100: 508 pp.

Zagwijn, W.H., 1989. The Netherlands during the Tertiary and the Quaternary: a case history of coastal lowland evolution. Geologie en Mijnbouw 68: 107-120.

Ziegler, P.A., 1978. Northwestern Europe: tectonics and basin development. Geologie en Mijnbouw 57: 589-626.

Ziegler, P.A., 1990. Geological Atlas of western and Central Europe (2nd. ed.). Shell Int. Petrol. Mij.: 239 pp, 56 encl. 